Prof. Predrag Cvetković, LL.D. *

ОРИГИНАЛНИ НАУЧНИ РАД

Full Professor,

Faculty of Law, University of Niš

doi:10.5937/zrpfn0-23298

UDK: 339.5:341.232

Рад примљен: 24.09.2019.

Рад прихваћен: 11.12.2019.

\title{
LAW AS A COMPLEX ADAPTIVE SYSTEM: PATH TOWARD SELF-SUSTAINABILITY OF LEGAL FRAMEWORK
}

\begin{abstract}
The topic of the paper is the possible implementation of the Complex Adaptive Systems (CAS) concept in the field of law. The CAS concept rests on the existence of a dynamic network with many actors (individuals, companies, states, and international institutions), acting simultaneously and constantly responding to the behavior of other actors in the network. The Complex Adaptive System is based on connections that are generated by gradual induction of certain rules; thus, the newly established order is not conditioned by a superior authority, but it functions as a self-regulated one. The CAS concept is not hierarchical, but heterarchical. Unlike the hierarchical structure, heterarchy is a structure that rests on a number of centers of equal standing in the system. The heterarhical system does not rest on the premise of fundamental unity, universal interests, and alike (as common features of the hierarchical system). Instead, the heterarchical system generates rules that cannot be observed and analyzed separately from the application process. The ability of actors or agents to respond to new challenges determines the adaptive character of this system. Applied to the field of law, the CAS concept is especially important when the legal situation at stake is prone to the change of the fundamentals on which it was based at the outset. The actors of the legal relationship (viewed as part of the CAS network) define mutual relations on the basis of the acquired experience resulting from the operation of the particular system. The Complex Adaptive System has tendency to retain patterns that have proved to be adequate and usable for a further process of self-construction of the order in the system. The factors driving and enabling the connection within the
\end{abstract}

\footnotetext{
*pepi@prafak.ni.ac.rs

** The paper is the result of research within the project "Protection of Human and Minority Rights in the European Legal Area" ( ${ }^{\circ}$ 179046), implemented by the Faculty of Law, University of Nis, and financially supported by the Ministry of Education and Science of the Republic of Serbia.
} 
elements of "law-oriented" complex adaptive systems are embodied in common values, principles and methods of interpretation. The paper illustrates the application of the CAS concept by providing the example of convergence among the agreements from the field of Foreign Investments Law (FIL).

Keywords: Complex Adaptive System; Autopoietic System; Foreign Investments Law.

\section{Introduction}

The Complex Adaptive System Theory attempts to understand the structure and behavior of complex systems, focusing on the cooperative interactions of individual components that give rise to unpredictable outcomes and events. The opposite concept is reductionism, based on the following presumption: the problem at stake is divided into smallest parts and analyzed from small to the most complex in order to respond to the posed questions. Complex systems are non-linear in terms of consequences: i.e., the results of the interaction among the parts of the non-linear system are not the sum of its parts. Furthermore, this sum also differs qualitatively from the sum of the added parts. Unlike nonlinear systems, the linear ones are characterized by the situation in which cause and effect have a clear causal relationship and scalable result. ${ }^{1}$ In the non-linear systems, collective actions on individual parts generate results which are difficult to predict. $^{2}$

1 The issue of scalability of legal norms rests on the following premises. Law as a system is based on the implicit notion that a legal norm is arbitrarily scalable, i.e. that a legal rule can adequately regulate matters within its scope, irrespective of their size and frequency. This unsubstantiated assumption leads to a partial overstrain of the law and corresponding dysfunctions. The issue of scalability can be illustrated with the following example. In customary international law, the compelling requirement of non-refoulement has emerged, according to which a refugee at the state border must not be rejected or returned to the home country. The application of this ethically inspired legal principle is possible without serious obstacles and tensions as long as the number the refugees (in terms of magnitude) remains acceptable to the receiving State. If this condition is no longer met (for example, because of a civil war), there is a mass flight of a huge number of people, and the application of the non-refoulment principle reaches its limits. In other words, the requirement of nonrefoulement is not an arbitrarily scalable norm of customary international law. The scalability issue is relevant in many disciplines (e.g., engineering, information technology and logistics) as a fundamental factor in the successful organization of production, transport and data transmission processes. Regarding the law, there is a considerable research deficit on the role and effect of scalability in legal discourse. See more in: Probst, T. Das Recht im Spannungsfeld von Sprache, Geist, Gesellschaft, Wirtschaft und Technik: Gedanken zur Phänomenologie des Rechts.Zeitschrift für schweizerisches Recht. - Basel. -Bd. 136(2017), Halbbd. 1, H. 3, p. 289-315.

2 The complexity is the third step in the continuum describing the level of intricacy attached to the issue concerned. The first one is the feature of simplicity (simple problems can be 
In non-complex systems, removing one element (which reduces the level of intricacy of the observed system) does not fundamentally alter the system's behavior apart from that which directly resulted from the piece that was removed. Complexity arises when the dependencies among the elements become important. In such a system, removing one such element influences the system operations to an extent that goes well beyond what is embodied by the particular element that is removed (Miller, Page, 2009: 9).

\section{Complex Adaptive System Theory}

The application of the Complex Adaptive System Theory in the field of law has its roots in the teaching of Niklas Luhmann. He posits that one system is always part of environment of the other one. People cannot exist without social systems (Luhmann, Rechtswissenschaftler, 1984: 92). However, those systems do not coincide. There are boundaries between them, produced by virtue of communication in the framework of the system concerned (Luhmann, Rechtswissenschaftler, 1984: $191 \mathrm{ff}$ ).

The law is seen as a subsystem of the social system functionally similar to other subsystems, such as: politics, economy, education, etc. Law has the function of stabilizing normative expectations (Luhmann, 2008: $94 \mathrm{ff}$ ). Viewed as a complex system, law communicates in terms of binary code: certain fact is either legal or illegal (Luhmann, 2008: 66-75). Legal communications are those belonging to the system: they are unresponsive to the communications from different system (weather forecast, political gossiping, or bribe). It is true that legal norms are applied to situations which, as such, are not part of the legal system. But, it is the law itself that determines what circumstances are relevant according to legal criteria. Therefore, Luhmann describes the law as an operationally closed system (Luhmann, 2008: $38 \mathrm{ff}$ ). Legal system is closed because every communication refers to the norm which is, by definition, part of the legal system.

The "operative closure" of a system becomes possible because it can distinguish itself from its environment. What distinguishes a form of communication so that it is recognizable as belonging to the legal system? Luhmann's answer is that law can distinguish itself from its environment by judging it in order to make

solved and their outcomes predicted with great precision because cause equals effect); the second one is "complication" (complicated problems contain a subset of simple problems; yet, once resolved, they do not require further solving); the third one is complexity of the problem. Simple and complicated problems are within the boundaries of cause equals effect. The relationship between cause and effect in the discourse of complex problems is outside the framework of the for egoing "cause-effect" relationship. See more in: Giudice, J. M. (2016). Through the Lens of Complex Systems Theory: Why Regulators Must Understand the Economy and Society as a Complex System. U. Rich. L. Rev., 51, 7.p. 105. 
the distinction between right (legal) and wrong (illegal) as the differentiation criteria. The unity of the legal system emerges from the following premise: all communications within the system are related to the dichotomy of right and wrong. Other systems have different core idea that forms the basis for communications with the system: economy is the system in which all communications deal with value and cost; science is about true and false, etc. This very core idea is a differentiation criterion for distinguishing the system at stake from its environment formed by other systems.

Communications that are based on the legal/illegal dichotomy can be made by anyone at any time and at any place. The boundaries of the law as a set of all lawrelevant communications thus run across all institutions and organizations. A legal system reduces this complexity by using actions as the communication unit (Luhmann, 1993: $74 \mathrm{ff}$ ). Namely, the legal system in a narrower sense comprises acts that cause legal consequences. The content of the law is based on certain acts: all subsequent operations of the law have to take into account the previous communications (embodied in the communication unit-particular action). One communication always connects to another. Many communications evoke new communications relating to earlier communications within the system: e.g., a court responds to the submitted complaint by instituting civil proceedings and, in the end, the court "communicates" the judgment.

In the context of Luhmann`s theory, law is viewed as an autopoietic system. An autopoietic system is capable of reproducing and maintaining itself. ${ }^{3}$ In the same vein, the legal system viewed as a communication network has the ability to reproduce itself from its element. Therefore, legal system is labeled as an autopoietic one: legality cannot be obtained from the environment outside of the law as a whole (Luhmann, 1993: 69). In other words, the law reproduces

3 The word is composed of Greek words ("auto"= self and poiesis = creation, production). The term was introduced by Chilean biologists Humberto Maturana and Francisco Varela to define the self-maintaining chemistry of living cells. The concept has been applied ever since to the fields of cognition, systems theory, and sociology. See: Maturana, H.R. and Varela, F.J., (1991). Autopoiesis and cognition: The realization of the living (Vol. 42), Springer Science \& Business Media. According to the authors, an autopoietic machine is organized as a network of processes of production (transformation and destruction) of components which: (i) through their interactions and transformations continuously regenerate and realize the network of processes (relations) that produced them; and (ii) constitute the system as a concrete unity in space in which its exist by specifying the topological domain of its realization as such a network (Maturana, Varela, 1991: 78). The opposite of an autopoietic system is an allopoietic system (allopoietic $=$ made by a stranger's hand), where the final result is different from the system that produces it; an illustrative example is the car assembly line that delivers a car different from the machines that produce it. 
itself in a recursive process where new system operations always tie in with the network of own operations.

Autopoietic systems, including the legal system, are reflexive: they can observe themselves at work. They can direct their operations to prioritize their own identities by using the guiding distinction that sets them apart from their environment. Their identity is generated by self-observation. Mutatis mutandis, within the legal system, the system boundaries are constantly self-monitored and self-controlled by internal tools established by the legal system itself.

Since the legal system is concerned with norms, the separation between law and other systems forming its environment is restricted to the normative one. Cognitively, the legal system remains open (informational openness). Of course, in the legal system, one can take note of what is happening in the world. But, the system can only react to that with its own yardsticks. ${ }^{4}$

Today, in the field of jurisprudence, Luhmann's systems theory is primarily influenced by Gunther Teubner. In 1989, Teubner elaborated his ideas of systems theory as the basis of sociology of law (Teubner, 1989: $20 \mathrm{ff}$ ). He absorbed the notion of the autopoiesis of the legal system. Thus, Autopoiesis and the autonomy of the legal system are not simply the result of self-referential linking of legal communications, but the recursive combination of results of connections. Teubner's view is that legalization of society always means the socialization of law. This is not to be understood simply as an "interaction" between law and the social subsystem, but as a dynamic cumulative process in which a "chain of misreadings" is built, driving both systems forward in a dynamic of misunderstandings. Legalization of society means that social phenomena (e.g. political or economic ones) are re-read into the language of law and transformed into legal phenomena and processed as legal realities. Socialization of law means that new legal phenomena (formed as the result of "legalization" of societal ones) are again perceived and reconstructed back in the realm of societal relations, and so on. Teubner posits that interaction between law and its environment (other subsystems, such as politics and economy) is an infinite process of mutual reading of newly produced realities (Teubner, 1997: 24). He added the expla-

4 The normative separation (closure) and informational openness of a legal system can be illustrated in comparison with the function of hospitals. Hospitals cannot abolish accidents (the health care system is separated from the interior affairs bodies) but they must do their best to take good care of the injured. Accordingly, for example, courtscannot print money to compensate for the financial lost but they can resort to their own resources by awarding damages in response to a properly substantiated claim. The normative closure is not without leaks: non-systemic communication forms the "noise" and potentially "irritates" the system as a whole. In law (especially in international law lacking the overarching authority), "noises" could have political value and, as such, they tend to be transformed into the normative realm. 
nation regarding the "noise" and "irritations" in terms of Luhmann`s approach. The "noises" are the result of the clash of rationalities (labelled by Teubner as "intrinsic logic") peculiar for each subsystem (politics, economy, etc). Every social sphere of action develops its idiosyncratic formal rationality, which is in an indissoluble conflict with the rationalities of other areas (Teubner, 2007: 116). This conflict arises because the social functional systems are presented as expansive: politics wants to politicize everything; economics endeavours to economize everything; the law attempts to justify both, etc. This position reflects the Luhmann`s concept of the core idea as the differentiation criterion. ${ }^{5}$

\section{International law as a complex adaptive system}

The international legal system consists of many diverse components influencing its evolution. The main feature of those components is their heterogeneity: states, international organizations, international and national courts and tribunals, non-governmental organizations, and individuals, which all differ in critical characteristics. Therefore, the development of international law is a complex process due to the number of contributors with non-identical (and frequently quite opposite) aims, methods and origins. The international legal system is generally a product of international relations and the continual formal and informal relationships between the actors from political, cultural, scientific and military spheres.

This reveals two important complex properties of the international legal system.

First, states, institutions and organizations are constantly re-defining their aims in accordance with their own dynamics as well as the one relevant for international discourse. Hence, international law norms create rules of conduct that are by no means continuously scalable and linear. ${ }^{6}$

Second, the various classes of different autonomous components of international law indicate the heterogeneity of the international legal system's actors. In order to achieve any significant international legal development, the support of the majority of states is needed. However, all states are legally independent and their interests and aims vary. According to the complexity theory, this diversity is not random; on the contrary, it is the result of the environment of the specific system and the actions of other states. Consequently, it is plausible to posit that international law is a decentralized system.

5 See more about differentiation criterion supra in part 2.

6 See more about scalability and linearity as the feature of legal norms supra in footnotes 1-2 and accompanying text. 
However, the application of the Complex Adaptive System Theory to international law lacks some elements which are present in the national set of norms; for example, what is the core norm of certain field of International Law? Ruhl calls it a deterministic rule (Ruhl, 2007: 901). This particular issue could be prevailed by adding more dynamic into the understanding of international law as a complex adaptive system (using Teubner's recursive feature of interactions between law and other subsystems). In order to be efficient, international mechanisms and institutions should be governed as a complex adaptive system: adaptive or decentralized governance is more suitable than the classical hierarchical structures of the international legal order. In effect, by applying the principles of complex adaptive systems to international law and its different actors, institutions and forms, the system's operational format becomes clearer, which eventually enables to seek response to questions regarding the system operative methods and goals. In terms of International Economic Law, there is a huge number of international agreements with an overlapping object of regulation which mutually influences their respective content, legal strength and place in the hierarchy of legal norms; for example, EU members are obliged to observe the EU rules as well as the rules generated within the framework of the World Trade Organization.

\subsection{International Law on Foreign Investments as an example of a complex adaptive system}

Like other social structures, International Law on Foreign Investments (ILFI) has the qualities of a complex adaptive system.

First of all, ILFI was not introduced via some "grand design" or "major constitutional moment" (Pauwelyn, 2014: 385) in a one-time endeavor; similar to other legal disciplines, it emerged gradually from a series of steps. In a way, this emerging path was incremental in the sense that no quant leap is observable from the up-to-date dynamic of ILFI development. The main vector for the establishment and evolution of the substantive ILFI framework were Bilateral Investment Treaties (BITs). ${ }^{7}$ On the procedural side of ILFI continuum, there was the establishment of the International Centre for Settlement of Investment Disputes (ICSID), which provided legitimate and efficient forum for settlement of investment disputes; however, it took more than two decades to make the ICSID fully effective in terms of the number of cases resolved before the Center. The result of this process is that ILFI is the result of overlapping, intersected and not always visible motives, actors, processes and forms. In one way or another, the

7 About BITs and other sources of ILFI see more in: Sornarajah, M. (2017). The international Law on Foreign Investment. Cambridge University Press. 
role of states, academic community, business circles and particular industries influenced the content and format of IFIL as a fully fledged part of international law. "There is no single creator, plan or deliberate design. Rather, it is large and small steps, influences and interactions which together organically produced and continue to drive FIL" (Pauwelyn, 2014: 378).

Consequently, it is plausible to conclude the following: ILFI is a decentralized system. Unlike WTO or EU law, it is based on the network of bilateral treaties (BITs), regional and multilateral agreements (such as ICSID), with the proper role of customary international law, national legal systems, and insurance schemes (such as MIGA). No unified driving political or economic force is beyond the system. The diversification of substantive rules corresponds to the multiplicity of procedural forums assigned with the task of resolving investment disputes (e.g. ICSID, institutional arbitrations, ad hoc arbitrations). So, as other complex adaptive systems, ILFI is not based on hierarchy but on interactions among different subsystems (agreement, conventions) without the central authority.

Second, the cohesion inside of system exists alongside with the dynamism of the system's structure: ILFI is a non-static structure whose flexibility is reflected in interaction among element of the system as such (agreements, custom international law, arbitral decisions, academic jurisprudence in the sense of Article 38 (1) of the Statute of the International Court of Justice). Cohesion is preceded by connection. Connectivity is realized through principles contained in certain clauses of investment agreement. ${ }^{8}$ An illustrative example is the Most-FavoredNation (MFN) treatment principle. The foregoing principles enable internal consistency of the system, and ensures that waves of change in certain part of the system can reach other parts of the structure: for example, if the content of one BITs changes, then the content of tertium comparationis as defined in other BITs changes by virtue of a MFN clause. Several tribunals have held that MFN clauses in the BITs, governing the disputes at hand, directly incorporated into the basic treaty more favorable substantive investment protection from the BITs between the host State and third countries. They, therefore, accepted that investors covered under the basic treaty could directly rely on the more favorable treatment granted to other foreign investors under their respective BITs. (Schill, 2009: 519). The previous description adds plausibility of the conclusion about the autopoietic nature of ILFI.

8 See more about Investment agreements in: Dolzer, R., Schreuer, C. (2012). Principles of international investment law. Oxford University Press. 


\section{Conclusion}

Legal systems often display the key characteristics of complex adaptive systems: decentralization as a guiding principle, accompanied with the lack of central authority; gradual and incremental emergence; dynamics and flexibility of the system; cohesion and regeneration of the system achieved through interactions and transformations of its components. Accordingly, by applying the principles of complex adaptive systems to international law system`s operational format, we can clearly identify driving forces, motives and possible development's directions. In terms of International Economic Law, there is a huge number of international agreements overlapping in the object of regulation and mutually influencing their respective content, legal strength and place in the hierarchy of legal norms (e.g. EU members are obliged to observe the EU rules as well as the rules generated in the framework of World Trade Organization). The understanding of the complexity theory foundations holds important lessons for legislators and regulators. The creators of statutes, rules and regulations must better understand the ramifications of complicated rules applied to a complex system. Looking at these problems through the lens of the complexity theory will give them a broader understanding of the complex problems they are trying to solve. The very emergence, structure and internal interaction of elements of International Law on Foreign Investments are an effective illustration of legal framework showing the essential qualities of a complex adaptive system: it is a decentralized system created in incremental and gradual steps, with interaction of self-contained elements as the key generator of regeneration and transformation of its content (legal rules); cohesion and flexibility are complementary rather than opposite elements. The core features of ILFI justify the efforts of certain segment of international law jurisprudence to accept (even counter-intuitively) that fragmentation and decentralization are not always ostracized from the legal discourse; in certain cases, the systems with those characteristics can be more effective in the long-run.

\section{References}

Giudice, J. M. (2016). Through the Lens of Complex Systems Theory: Why Regulators Must Understand the Economy and Society as a Complex System. U. Rich. L. Rev., 51, 7.

Luhmann, N. (1993) Das Recht der Gesellschaft. Frankfurt am Main 64.

Luhmann, N. (2008). Rechtssoziologie. Springer-Verlag.

Luhmann, N., Rechtswissenschaftler, S. (1984). Soziale systeme: grundriss einer allgemeinen theorie (Vol. 242). Frankfurt am Main: Suhrkamp. 
Maturana, H.R., Varela, F.J., (1991). Autopoiesis and cognition: The realization of the living (Vol. 42). Springer Science \& Business Media.

Miller, J. H., Page, S. E. (2009). Complex adaptive systems: An introduction to computational models of social life (Vol. 17). Princeton University Press.

Pauwelyn, J. (2014). At the edge of chaos? Foreign investment law as a complex adaptive system, how it emerged and how it can be reformed. ICSID Review, 29(2), 372-418.

Pauwelyn, J. (2014). At the edge of chaos? Foreign investment law as a complex adaptive system, how it emerged and how it can be reformed. ICSID Review, 29(2), 372-418.

Probst, T. (2017). Das Recht im Spannungsfeld von Sprache, Geist, Gesellschaft, Wirtschaft und Technik: Gedanken zur Phänomenologie des Rechts. Zeitschrift für schweizerisches Recht. - Basel. -Bd. 136 (2017), Halbbd. 1, H. 3, p. 289.

Ruhl, J. B. (2007). Law's complexity: a primer. Ga. St. UL Rev., 24, 885-911.

Sornarajah, M. (2017). The international law on foreign investment. Cambridge University Press.

Teubner, G. (1989). Recht als autopoietisches System, Suhrkamp Verlag Frankfurt am Main.

Teubner, G. (2007). Globale Zivilverfassungen: Alternativen zur staatszentrierten Verfassungstheorie (pp. 115-147). Nomos Verlagsgesellschaft mbH \& Co. KG.

Teubner, G. (1997). Verrechtlichung-ein ultrazyklisches Geschehen. Institut für Staatswissenschaften der Universität der Bundeswehr. 


\author{
Др Предраг Цветковић, \\ Редовни професор, \\ Правни факултет, Универзитет у Нишу
}

\title{
ПРАВО КАО КОМПЛЕКСНИ АДАПТИВНИ СИСТЕМ: ПУТ КА САМООДРЖИВОСТИ ПРАВНОГ ОКВИРА
}

\begin{abstract}
Резиме
Теорија комплексних адаптивних система бави се структуром и функционисање комплексних феномена. Комплексни системи су не-линеарни у контексту последица: резултати интеракција између елемената таквог система нису прост збир њихових вредности. Посматрано као комплексни систем, право карактерише функционисање у бинарном моду: одређени факт је противправан или је правно ваљан. Управо се јединство правног система заснива се на следећој премиси: све интеракције унутар правног система сагледавају се кроз призму противправности или сагласности са нормом. Даље, комплексни адаптивни системи су аутопоиетични у смислу да су способни да се репродукују и одржавају међусобним интеракцијама. Како и право као систем има могућност да се препродукује из сопствених елемената, може оправдано да се окарактерише као аутопоиетични систем; наиме, суд о сагласности одређене чињенице са правном нормом не може да се обезбеди из дискурса који је ванправни. Уконтексту међународног права, његов развој је комплексан процес у коме учествују различити актери са неподударним интересима. Међународно право има две карактеристике које га чине сложеним системом у контексту теорије комплексних адаптивних система. Прво, правила међународног права нису линеарна и скалабилна у примени. Друго, различите независне компоненте међународног права индицирају хетерогеност његових актера. У складу са напред наведеним, оправдано је да се закључи да је међународно право децентрализовани систем. Илустративни пример комплексног адаптивног система из корупса међународног права је међународно право страних инвестищија. Оно није настало као резултат “кровне замисли” већ је настало као резултат не-хијерархијске интеракције између различитих елемената (споразуми, конвенције, међународне организације) без врховног ауторитета; дакле, деценетрализовано је. Друго, кохезија унутар овог система базирана је на повезаности коју обезбеђују принципи попут принципа најповлашћеније нације. Стога боље разумевање теорије комплексних адаптивних система оправдава став да у одређеним ситуацијама фрагментирани и децентрализовани системи могу дугорочно да буду ефикаснији него они који такве особине немају.
\end{abstract}

Кључне речи: теорија комплексних адаптивних система, аутопоиетични систем, међународно право страних инвестиција. 